\title{
Atypical Hemolytic Uremic Syndrome Associated With Complement Factor H Autoantibodies and CFHR1/CFHR3 Deficiency
}

\author{
BEOM HEE LEE, SOO HEON KWAK, JAE IL SHIN, SO HEE LEE, HYUN JIN CHOI, HEE GYUNG KANG, IL SOO HA, \\ JAE SEUNG LEE, MARIE-AGNÈS DRAGON-DUREY, YONG CHOI, AND HAE IL CHEONG
}

\begin{abstract}
Department of Pediatrics [B.H.L., S.H.L., H.J.C., H.G.K., I.S.H., Y.C., H.I.C.], Kidney Research Institute [B.H.L., H.G.K., I.S.H., Y.C., H.I.C.], and Research Center for Rare Diseases [H.G.K., H.I.C.], Seoul National University College of Medicine, Seoul 110-744, Korea; Department of Public Health and Hygiene [S.H.K.], Gyeonggi Provincial Office, Uijeongbu City, Gyeonggi-do 480-764, Korea; Department of Pediatrics [J.I.S., J.S.L.], Yonsei University College of Medicine, Severance Children's Hospital, Seoul 120-749, Korea; Department of Immunology [M.-A.D.-D.], Hôpital Européen Georges Pompidou, Paris 75015, France
\end{abstract}

\begin{abstract}
Although genetic defect of complement factor $\mathrm{H}$ $(\mathrm{CFH})$ is a common cause of atypical hemolytic uremic syndrome (aHUS), development of autoantibodies to $\mathrm{CFH}(\mathrm{CFH}-\mathrm{Ab})$ is also known to be an acquired cause of aHUS. Recently, a correlation between the development of $\mathrm{CFH}-\mathrm{Ab}$ and the deficiency of the CFH-related proteins, CFHR1 and CFHR3, was identified. In this study, plasma complement profiles were measured and genetic analysis of the $C F H, C F I, M C P, C F H R 1$, and $C F H R 3$ genes were performed in three female patients diagnosed with aHUS with positive $\mathrm{CFH}-\mathrm{Ab}$. Acute stage plasmas of all the three patients revealed low $\mathrm{C} 3$, low or low-normal CFH antigenic levels, and high titers of $\mathrm{CFH}-\mathrm{Ab}$. All the patients also showed complete plasma CFHR1 deficiency and homozygous genomic deletion of $C F H R 1 / C F H R 3$, but none had $C F H, C F I$, or $M C P$ mutations. All the patients were treated with plasmapheresis, and two patients required additional immunosuppressive therapy. These patients had a novel subgroup of aHUS characterized by a combination of genetic (a homozygous deletion of CFHR1/CFHR3) and acquired (development of CFH-Ab) factors. Patients with this disease may need intensive immunosuppressive therapy in addition to plasmapheresis. Screening for $\mathrm{CFH}-\mathrm{Ab}$ and the CFHR1/CFHR3 deficiency should be included in the diagnostic tests for patients with aHUS. (Pediatr Res 66: 336-340, 2009)
\end{abstract}

$\mathrm{H}$ emolytic uremic syndrome (HUS) is a clinical syndrome characterized by microangiopathic hemolytic anemia, thrombocytopenia, and acute renal failure (1). In $\sim 90 \%$ of childhood cases, HUS follows a prodrome of diarrhea, which is typically caused by verocytotoxin-producing Escherichia coli (1). However, atypical cases (aHUS) without preceding diarrhea also occur. These cases show a tendency to relapse, to occur in families, and to have a poor outcome $(1,2)$. Recent advances have shown that aHUS is a disease of complement dysregulation, and that loss-of-function mutations were detected in $\sim 50 \%$ of cases in one of the three complement regulator genes: the $\mathrm{CFH}$ gene encoding complement factor $\mathrm{H}$

Received March 5, 2009; accepted May 13, 2009

Correspondence: Hae Il Cheong, MD, Department of Pediatrics, Seoul National University Children's Hospital, 28 Yongon-Dong, Chongro-Gu, Seoul 110-744, South Korea; e-mail: cheonghi@snu.ac.kr

Supported by a Grant A080588 from the Korea Healthcare technology R\&D Project, Ministry for Health, Welfare and Family Affairs, Republic of Korea and a Grant 06-2008-192-9 from the Seoul National University Hospital.
(CFH), the CFI gene encoding complement factor I, and the $M C P$ gene encoding membrane cofactor protein (CD46) $(3,4)$. In addition, few cases of aHUS were associated with gain-offunction mutations in complement activation proteins, complement factor B and C3, as described $(5,6)$. Among these mutations, $C F H$ mutations are the most common and account for $14-30 \%$ of aHUS cases $(3,4,7-10)$.

In addition to genetic defects associated with aHUS, acquired functional defects of $\mathrm{CFH}$ due to the development of anti-CFH autoantibodies (CFH-Ab) have been observed in $6-11 \%$ of aHUS cases (11-13). In 2008, Józsi et al.(13) isolated a strong correlation between the occurrence of $\mathrm{CFH}-\mathrm{Ab}$ and the genetic deletion of the CFHRI and CFHR3 genes by identifying 16 patients $(11 \%)$ with both defects in a cohort of 147 aHUS patients. The CFHRI and CFHR 3 genes, which are tightly linked to the $\mathrm{CFH}$ gene, encode $\mathrm{CFH}$-related protein 1 and 3 (CFHR1 and CFHR3), respectively $(14,15)$.

Here, we report three additional cases of aHUS positive for $\mathrm{CFH}-\mathrm{Ab}$ with deficiency of CFHR1/CFHR3. Although the mechanism involved in how CFHR1/CFHR3 deficiency leads to the generation of $\mathrm{CFH}-\mathrm{Ab}$ is currently unknown, it is clinically important to detect $\mathrm{CFH}-\mathrm{Ab}$ in deciding the treatment option for patients with aHUS. In patients with positive $\mathrm{CFH}-\mathrm{Ab}$, plasma infusion or plasmapheresis alone may be insufficient to restore hematologic and renal disturbances and need additional immunosuppressive treatments in the early phase of disease to reduce $\mathrm{CFH}-\mathrm{Ab}$ production.

\section{MATERIALS AND METHODS}

Patients. All the three patients were clinically diagnosed as aHUS, and stool culture and multiplex PCR tests for verotoxin-producing E. coli in their stools were negative. This study was approved by the Ethics Committee of Seoul National University Hospital, Seoul, Korea, and informed consent of parents of the each patient was obtained before DNA analysis.

Complement Assays. Plasma concentrations of the complement components C3, C4, and factor B antigens were measured by nephelometry

Abbreviations: aHUS, atypical hemolytic uremic syndrome; ANA, antinuclear antibody; CCP, complement control protein module; CFH, complement factor H; CFH-Ab, anticomplement factor $\mathrm{H}$ autoantibodies; CFHR, complement factor H-related protein; HUS, hemolytic uremic syndrome 
(Dade Behring, Paris La Defense, France). CFH and complement factor I antigen concentrations were measured by an ELISA method as described previously (16).

CFH-Ab Assessment. Presence of plasma CFH-Ab was detected by using an ELISA method as previously described (16). Briefly, ELISA plates were coated with $0.3 \mu \mathrm{g}$ of purified human CFH (Calbiochem, Meudon, France). After washing and blocking free reactive sites with PBS containing 1\% BSA, serially diluted sample plasmas were added to the ELISA plates for $1 \mathrm{~h}$ at room temperature. After washing, the plates were incubated for $1 \mathrm{~h}$ at room temperature with a horseradish peroxidase-conjugated goat antihuman IgG antibody (Sigma-Aldrich Chemical, Steinheim, Germany). After additional washing, enzymatic activity was revealed using the orthophenyldiamine substrate. Antibody titers were expressed as arbitrary units per $\mathrm{mL}(\mathrm{AU} / \mathrm{mL})$ calculated as $(S-B) \times 1000 /(P-B)$, where $S$ is OD of the test sample diluted at $1: 200, B$ is absorbency of the blank, and $P$ is absorbency of the reference positive plasma diluted (1:200) given an arbitrary titer of $1000 \mathrm{AU} / \mathrm{mL}$.

Western Blot Analysis. Plasma samples of the patients and their available family members were investigated by Western blotting by using an enhanced chemiluminescent kit (Amersham Life Science, Buckinghamshire, UK). Goat polyclonal anti-human CFH (Calbiochem, San Diego, CA) was used as a primary antibody (1:2500 dilution) and a horseradish peroxidase-conjugated donkey anti-goat IgG (Santa Cruz Biotechnology, Santa Cruz, CA) as a secondary antibody (1:2500 dilution). The pooled plasma of five healthy volunteers was used as a normal control. There are two differently glycosylated forms of CFHR 1 protein, CFHR $1 \alpha$ (one carbohydrate residue) and CFHR $1 \beta$ (two carbohydrate residues). Western blot analysis of the plasma of the control subjects revealed three strong bands. According to the binding capacity of the primary antibody, which can bind $\mathrm{CFH}$ and factor $\mathrm{H}$ like protein-1 (CFHL-1, an alternative splicing product of $C F H$ ) strongly and also bind CFHR1-5 weakly, the largest band represents CFH (150 kD) and two smaller bands represent CFHR $1 \alpha(37 \mathrm{kD})$ and a mixture of CFHL-1 and CFHR1 $\beta$ (43 kD). Specific antibodies against CFHR1 and CFHR3 were not available for this study.

Genomic DNA Analysis. The entire coding exons of $C F H, M C P$, and $C F I$ were amplified from peripheral blood genomic DNA by PCR and directly sequenced in all the three patients. In addition, to screen the homozygous deletion of CFHR1/CFHR3, genomic DNA was amplified by PCR using eight specific primer pairs (R1-R8 primer pairs described in Ref. 14) that cover the $100-\mathrm{kb}$ region downstream of the $C F H$ gene. We screened 100 control Korean subjects with this method, and the homozygous deletion of CFHR1/CFHR3 was detected in two subjects.

\section{RESULTS}

Patient 1. A 7-y-old girl was admitted to the hospital with abdominal pain, vomiting, gross hematuria, with a blood pressure of 110/64 mm Hg. Laboratory tests revealed microangiopathic hemolytic anemia $(\mathrm{Hb} 64 \mathrm{~g} / \mathrm{L}$, reticulocyte count $11.5 \%$, serum haptoglobin $<0.07 \mathrm{~g} / \mathrm{L}$ ), thrombocytopenia $\left(20 \times 10^{9} / \mathrm{L}\right)$, and azotemia [serum creatinine $274 \mu \mathrm{M}$, estimated GFR by Schwartz formula (17) $23 \mathrm{~mL} \cdot \mathrm{min}^{-1} \cdot 1.73$ $\mathrm{m}^{-2}$ ]. Her spot urine protein/creatinine ratio $[\mathrm{Pr} / \mathrm{Cr},(\mathrm{mg} / \mathrm{dL}) /$ $(\mathrm{mg} / \mathrm{dL})$ ] was 31.9. A stool culture and multiplex PCR test for verotoxin-producing $E$. coli in the stool were both negative. An antinuclear antibody (ANA) test was negative. The hemolytic process was not controlled by 10 sessions of daily plasmapheresis followed by a week of intermittent plasmapheresis (three times per week) and hemodialysis. Therefore, oral corticosteroid treatment $\left(2 \mathrm{mg} \cdot \mathrm{kg}^{-1} \cdot \mathrm{d}^{-1}\right)$ was started at day 18 and i.v. immunoglobulin $(1 \mathrm{~g} / \mathrm{kg})$ was administered twice at days 38 and 39 . The steroid and immunoglobulin treatment brought clinical improvement without further plasmapheresis. However, aHUS recurred at day 58 with abdominal pain and jaundice (serum total and direct bilirubin levels were 180 and $106 \mu \mathrm{M}$ ). The serum levels of hepatic (alanine aminotransferase $708 \mathrm{U} / \mathrm{L}$ ) and pancreatic enzymes (amylase $193 \mathrm{U} / \mathrm{L}$ ) were elevated, and abdominal ultrasonography revealed mildly swollen pancreas and fluid collection with septation in the peripancreatic space. Although the hepatic and pancreatic symptoms were relieved after 1 wk of supportive care and total restriction of oral intake, the hemolytic process was unresponsive to $1 \mathrm{wk}$ of daily plasmapheresis but the addition of oral azathioprine $\left(2 \mathrm{mg} \cdot \mathrm{kg}^{-1} \cdot \mathrm{d}^{-1}\right)$ to the treatment regimen resulted in a complete remission with the discontinuation of plasmapheresis. Laboratory tests conducted 5 mo after onset of symptoms revealed no evidence of hemolysis, but moderate renal insufficiency (serum creatinine $115 \mu \mathrm{M}$, estimated GFR $23 \mathrm{~mL} \cdot \min ^{-1} \cdot 1.73 \mathrm{~m}^{-2}$ ) with mild proteinuria. Oral corticosteroid treatment is currently being tapered (Table 1 and Fig. 1A).

Patients 2 and 3. These two patients, when compared with patient 1 , showed milder but very similar clinical features and laboratory findings, which were summarized in Fig. $1 B$, Fig. $1 C$, and Tables 1 and 2. Both patients had preceding nonbloody diarrhea with stools negative for enterohemorrhagic E. coli and verotoxin. In patient 2, stool was positive for norovirus RNA by RTPCR.

Complement and $\boldsymbol{C F H}-\boldsymbol{A b}$ assay. Table 2 summarizes the plasma complement profiles of these three patients. In all the three patients, the plasma $\mathrm{C} 3$ levels were decreased in the acute stage but normalized once in remission. The antigenic levels of CFH were low (Patients 1 and 3) or low normal (patient 2) during the acute stage; however, these levels were also normalized later during follow-up. The initial titers of the CFH-Ab were extremely elevated in all patients. After 3-11 mo of follow-up examinations, the $\mathrm{CFH}-\mathrm{Ab}$ titers decreased markedly but still above normal.

Western blot and genomic DNA analysis. When compared with three strong bands detected in the plasma of the control subjects, the $37 \mathrm{kD}$ band (CFHR $1 \alpha$ ) was completely lacking and the $43 \mathrm{kD}$ band (a mixture of CFHL-1 and CFHR $1 \beta$ ) was weaker in all the three patients, while the $150 \mathrm{kD}$ band $(\mathrm{CFH})$ was comparable. These findings suggest that the patients have a homozygous depletion of CFHR1 in their plasmas. The 37 and

Table 1. The clinical and laboratory findings of the patients

\begin{tabular}{|c|c|c|c|}
\hline & Patient 1 & Patient 2 & Patient 3 \\
\hline Age at onset (years)/gender & 7/female & 9/female & 10/female \\
\hline Family history & - & - & - \\
\hline Preceding diarrhea & - & $+*$ & + \\
\hline \multicolumn{4}{|l|}{ Initial laboratory findings } \\
\hline Hemoglobin $(\mathrm{g} / \mathrm{L})$ & 65 & 71 & 56 \\
\hline Reticulocytes (\%) & 11.5 & 4.8 & 7.5 \\
\hline Platelets $\left(\times 10^{9} / \mathrm{L}\right)$ & 20 & 18 & 18 \\
\hline Serum creatinine $(\mu \mathrm{mol} / \mathrm{L})$ & 274 & 265 & 557 \\
\hline $\mathrm{eGFR}\left(\mathrm{mL} \cdot \min ^{-1} \cdot 1.73 \mathrm{~m}^{-2}\right)$ & 23 & 26 & 13 \\
\hline Extrarenal involvement & $\begin{array}{c}\text { Liver/ } \\
\text { pancreas }\end{array}$ & $\begin{array}{c}\text { Liver/ } \\
\text { pancreas }\end{array}$ & Liver \\
\hline \multicolumn{4}{|l|}{ Management } \\
\hline Hemodialysis & + & - & + \\
\hline Plasma therapy & $\mathrm{PE}+\mathrm{PI}$ & $\mathrm{PE}+\mathrm{PI}$ & PI \\
\hline Immunosuppressants & $\mathrm{Pd} / \mathrm{AZT} / \mathrm{IVIG}$ & $\mathrm{Pd}$ & - \\
\hline Follow-up (months) & 5 & 14 & 6 \\
\hline No. of recurrence & 1 & 1 & 1 \\
\hline Final eGFR $\left(\mathrm{mL} \cdot \min ^{-1} \cdot 1.73 \mathrm{~m}^{-2}\right)$ & 54 & 127 & 112 \\
\hline
\end{tabular}

* Nonbloody diarrhea associated with positive stool norovirus RNA by RT-PCR

PE, plasmapheresis; PI, fresh frozen plasma infusion; Pd, oral prednisolone; AZT, azathioprine; IVIG, intravenous immunoglobulin G; eGFR, estimated glomerular filtration rate by Schwartz formula. 


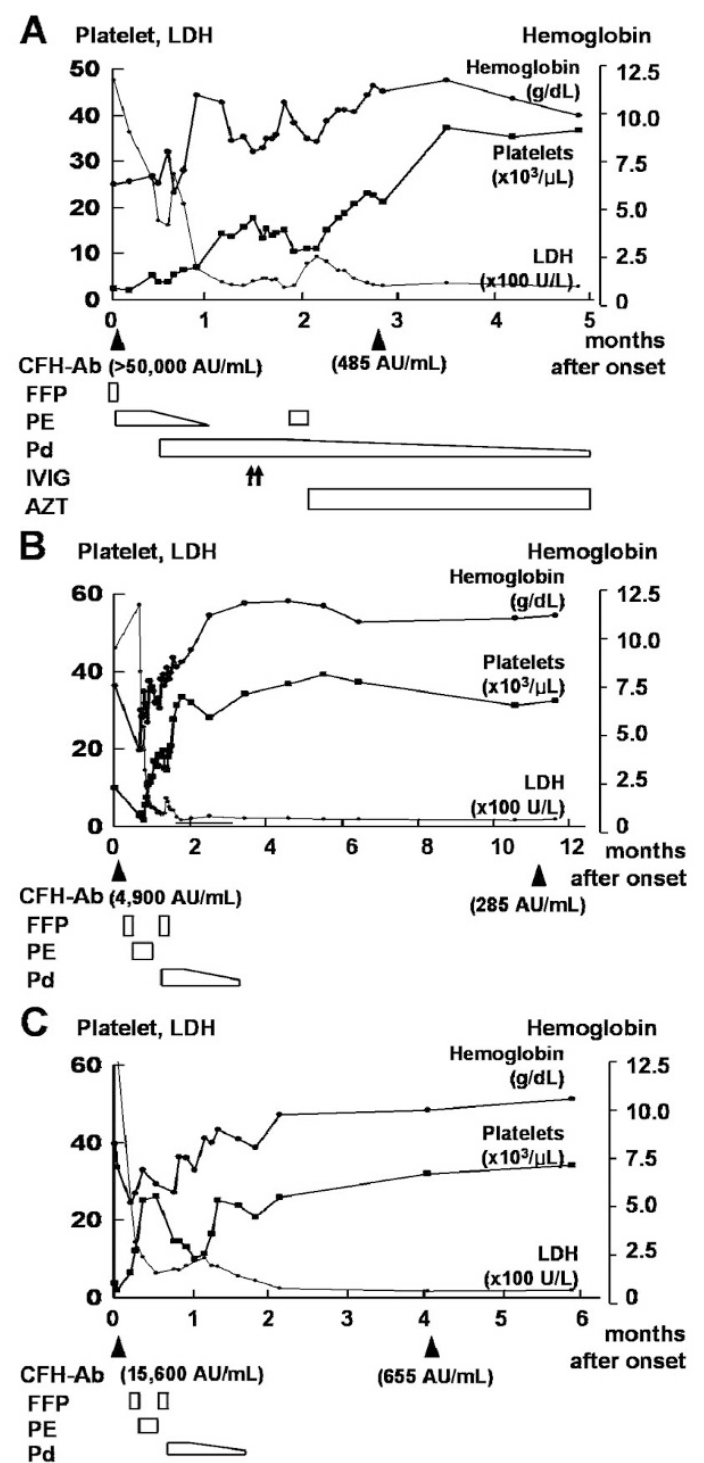

Figure 1. The clinical courses of three patients $(A$, patient $1 ; B$, patient 2 ; $C$, patient 3). LDH, lactic dehydrogenase; FFP, fresh frozen plasma infusion; PE, plasmapheresis; HD, hemodialysis; Pd, oral prednisolone; AZT, azathioprine; IVIG, i.v. IgG.
$43 \mathrm{kD}$ bands of the parents of patient 1 were weaker than those of the controls, which suggests a heterozygous deletion (Fig. 2). Finally, the homozygous deletion of the CFHR1/CFHR3 genes was confirmed by failure of PCR amplification of the genomic DNA fragments within or near both genes in all the three patients (Fig. 3).

No pathogenic mutations of the $C F H, C F I$, and $M C P$ genes were detected in any of the patients.

\section{DISCUSSION}

$\mathrm{CFH}$, a serum glycoprotein, is composed of 20 consecutive homologous units called complement control protein modules, each comprising $\sim 60$ amino acids (18). CFH is a central fluidphase regulator of the alternative pathway of complement, having both cofactor and decay-accelerating activity (19). The majority (60-70\%) of $C F H$ mutations is heterozygous missense mutations that cluster in the $\mathrm{C}$-terminal region of $\mathrm{CFH}$, a heparin binding domain (20-22). Such mutants show decreased binding for glycosaminoglycans, endothelial cells, and $\mathrm{C} 3 \mathrm{~b}$, the $\mathrm{CFH}$ ligand (20,23-25). In addition to genetic defects involving $C F H$ or other complement regulator genes, aHUS may also result from an acquired defect such as the development of $\mathrm{CFH}-\mathrm{Ab}$ (11-13). The binding epitopes of the $\mathrm{CFH}-\mathrm{Ab}$ are localized to the $\mathrm{C}$ terminal recognition region of $\mathrm{CFH}$, which is a hot spot for genetic mutations $(11,12)$.

The role of CFHRs has also been studied as a cause of aHUS. The genes for CFH and CFHR1-5 are all tightly linked in the regulators of complement activation (RCA) gene cluster at chromosome 1q32. This site is a hot spot for gene conversion events as well as genomic rearrangements (26-28), and a role for gene conversion in generation of $\mathrm{CFH}$ mutants associated with aHUS was proved (28). In addition, it is recently known that a haplotype containing a deletion of CFHRI/CFHR3, which may result from a nonallelic homologous recombination between $C F H$ and $C F H R I$, is detected in $\sim 2 \%$ of normal population (11), and this polymorphism has been demonstrated to increase the risk of aHUS (29).

Finally, in 2008, Józsi et al. (13) identified a strong correlation between the occurrence of $\mathrm{CFH}-\mathrm{Ab}$ and the absence or reduction of plasma CFHR1/CFHR3. In a large cohort of 147 patients with aHUS, they found $22(15 \%)$ patients had total or near total

Table 2. Complement component profiles of the patients based on acute and convalescent plasmas

\begin{tabular}{|c|c|c|c|c|c|c|c|}
\hline & \multicolumn{2}{|c|}{ Patient 1} & \multicolumn{2}{|c|}{ Patient 2} & \multicolumn{2}{|c|}{ Patient 3} & \multirow[b]{2}{*}{ Normal ranges } \\
\hline & Acute & Conv & Acute & Conv & Acute & Conv & \\
\hline $\mathrm{C} 3$ & 0.54 & 1.10 & 0.42 & 0.91 & 0.68 & 1.39 & $0.70-1.50 \mathrm{~g} / \mathrm{L}$ \\
\hline $\mathrm{C} 4$ & 0.26 & nd & 0.33 & nd & 0.23 & nd & $0.10-0.35 \mathrm{~g} / \mathrm{L}$ \\
\hline Factor B Ag* & 0.16 & 0.09 & 0.13 & 0.10 & 0.21 & 0.18 & $0.09-0.32 \mathrm{~g} / \mathrm{L}$ \\
\hline Factor $\mathrm{H} \mathrm{Ag} \dagger$ & 60 & 103 & 73 & 109 & 58 & 123 & $65-140 \%$ \\
\hline Factor I Ag $\dagger$ & 104 & 111 & 82 & 91 & 115 & 131 & $70-130 \%$ \\
\hline $\mathrm{CFH}-\mathrm{Ab} \ddagger$ & $>50,000$ & 485 & 4,900 & 285 & 15,600 & 656 & $<100$ \\
\hline
\end{tabular}

Acute plasma was collected before any plasma therapy in all three patients, and the convalescent plasma was collected at 3 months in patient 1 , at 11 months in patient 2, and at 4 months after the onset. The duration between the collection date of convalescent plasmas and the last plasma therapy was 1 month in patient 1, 9 months in patient 2 , and 3 months in patient 3 .

* Determined by nephelemetry.

$\dagger$ Determined by ELISA.

\$ Arbitrary units calculated using a reference positive plasma given an arbitrary titer of $1000 \mathrm{AU} / \mathrm{mL}$.

Conv, convalescent; nd, not determined; Ag, antigenic level. 


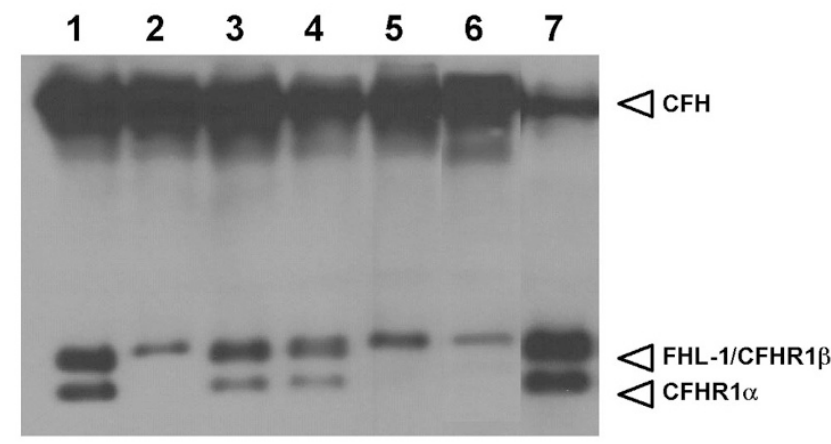

Figure 2. Western blot analysis of plasma using a commercial polyclonal anti-human $\mathrm{CFH}$ antibody. Three bands are seen in lane 1 (pooled control plasmas); CFH of $150 \mathrm{kD}$, CFH-related protein $1 \alpha$ (CFHR $1 \alpha$ ) of $37 \mathrm{kD}$, and a mixture of CFH-like protein-1 (FHL-1) and CFHR $1 \beta$ of $43 \mathrm{kD}$. The $37 \mathrm{kD}$ band was completely lacking and the $43 \mathrm{kD}$ band was weaker in all the three patients (lanes 2, 5, and 6, respectively), which suggests a complete lack of CFHR $1 \alpha /$ CFHR $1 \beta$. The parents of patient 1 (lanes 3 and 4 ) showed weaker 37 and $43 \mathrm{kD}$ bands than the controls, which suggests a heterozygous deficiency of CFHR $1 \alpha /$ CFHR $1 \beta$. Lane 7 is the plasma of a patient with a CFH mutation.

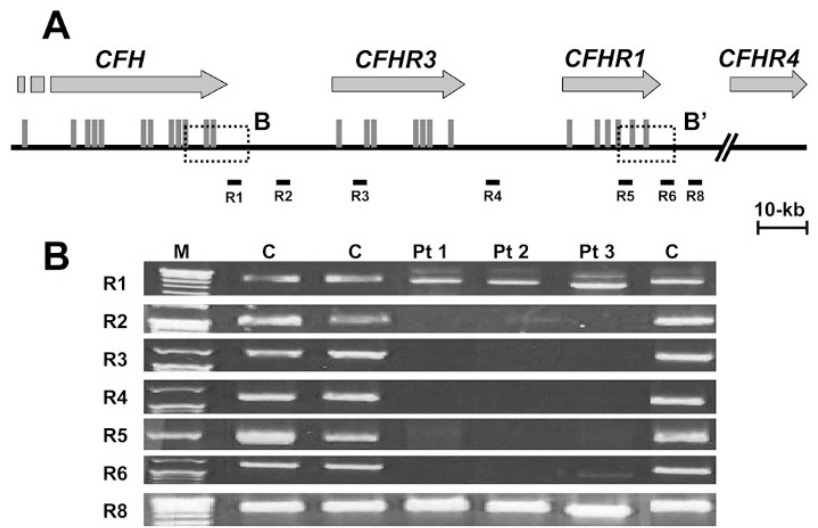

Figure 3. Panel A: A partial map of the human RCA gene cluster on chromosome 1q32 showing four genes ( $C F H, C F H R 3, C F H R 1$, and CFHR4) in tandem arrangement. Exons are indicated as gray vertical lines, and the positions of the two duplicated homologous segments $\left(B\right.$ and $\left.B^{\prime}\right)$ and the eight primer pairs (R1-R8) are shown. Panel $B$ : Failure to amplify DNA downstream of $C F H$ (R2-R6) was noted in all the three patients (Pt 1, Pt 2 and Pt $3)$, whereas the DNA was amplified in the control subjects $(C)$. These results suggest a homozygous genomic deletion of $C F H R 1 / C F H R 3$ due to recombination between segments $B$ and $B^{\prime}$. M, molecular size markers.

CFHR1/CFHR3 deficiency and 16 (11\% of the total) of those patients were positive for CFH-Ab. Furthermore, no patients developed CFH-Ab that did not have a CFHR1/CFHR3 deficiency. These findings suggest that CFHR1/CFHR3 deficiency may favor the development of CFH autoantibody. However, the mechanism by which the CFHR1/CFHR3 deficiency leads to the generation of $\mathrm{CFH}-\mathrm{Ab}$ is currently unknown. Small portion of healthy control subjects and some patients with aHUS have CFHR1/CFHR3 deficiency but not CFH-Ab $(11,13)$. Several clinically unaffected family members of the patients with CFHR1/CFHR3 deficiency and CFH-Ab also showed CFHR1/ CFHR3 deficiency without CFH-Ab (13). These findings suggest that the CFHR1/CFHR3 deficiency itself is not sufficient for the development of CFH-Ab and aHUS.
Since three French cases of aHUS associated with $\mathrm{CFH}-\mathrm{Ab}$ were first described by Dragon-Durey et al. in 2005 (12), a total of 24 patients with aHUS associated with $\mathrm{CFH}-\mathrm{Ab}$ have been reported with the frequency of $6-11 \%$ among patients with aHUS (11-13). However, the CFHRI/CFHR3 genes were studied in 16 patients of the latest study (13) only, and all 16 have deletion of both genes. Our study presents three additional cases with aHUS associated with a CFH-Ab and a homozygous deletion of CFHR1/CFHR3.

Almost all the previously reported patients with $\mathrm{CFH}-\mathrm{Ab}$ positive aHUS as well as our patients were juvenile, suggesting a preferential age in preadolescent children (11-13). Conversely, aHUS associated with $C F H$ mutations starts earlier in children, including the neonatal period (4). In addition, the three cases reported here and two of the three French cases (12) showed extra-renal involvements, especially in the liver and pancreas. Conversely, extrarenal involvement in patients with other forms of aHUS has been reported uncommon (4).

In the three French cases (12), the CFH assays were not performed during the acute phase for two of the patients and their plasma $\mathrm{CFH}$ activity decreases, whereas their plasma $\mathrm{CFH}$ antigenic levels were normal. Conversely, although the $\mathrm{CFH}$ activity was not measured in our cases, the $\mathrm{CFH}$ antigenic levels were low or low normal in plasma samples collected during the acute stage but were normalized in plasma collected during the convalescent stage. Based on these results, one can speculate that rapid development of a very large amount of CFH-Ab may lead to a transient decrease in circulating $\mathrm{CFH}$. Therefore, a decreased plasma CFH antigenic level in a patient with aHUS does not exclude the possibility of CFH-Ab-associated aHUS.

All the three French patients were ANA positive (12). Similarly, ANA is frequently detected in adult patients with idiopathic thrombotic microangiopathies associated with acquired ADAMST-13 deficiency (30). Conversely, none of the patients in our study exhibited ANA. However, we currently have no explanation for this difference.

In majority of patients with aHUS with/without known genetic mutations, the illness is preceded by a triggering condition such as a nonspecific infection (3). Indeed, all the three patients in our study as well as the three French cases (12) involved a preceding diarrheal illness and/or gastrointestinal symptoms. Therefore, it is likely that a triggering nonspecific infection alters the immunologic response of the host and leads to the development of autoantibodies. This phenomenon is probably more likely to occur in hosts with a genetic defect of CFHR1/CFHR3.

Genetic diagnosis of patients with aHUS can provide relevant information that can be used to predict survival, renal recovery, and transplant outcome. Overall, patients with $M C P$ mutations have a milder form of the disease than those with either $C F H$ or CFI mutations, and many of these patients recover without plasma therapy (3). In addition, screening for CFH-Ab in aHUS patients would be helpful for planning a therapeutic strategy, as patients with $\mathrm{CFH}-\mathrm{Ab}$ may require intensive immunosuppressive therapy as well as plasma infusion or plasmapheresis. Plasma therapy, which is the mainstay of treatment of aHUS, can remove circulating $\mathrm{CFH}-\mathrm{Ab}$, but such treatment cannot block ongoing production of the autoantibodies. The required intensity of immunosuppressive therapy for individual patients may be 
proportional to the degree of $\mathrm{CFH}-\mathrm{Ab}$ production of each patient. All the three patients reported here and the three French patients (12) had recurrences of aHUS, when plasma therapy was stopped. Most likely, this was due to a rebound of $\mathrm{CFH}-\mathrm{Ab}$, which was subsequently prevented by the addition of steroid and/or azathioprine to plasma therapy in four of them. These findings suggest that more aggressive immunosuppressive treatment should be started earlier to prevent this sequel and tapering if this treatment should be guided by serial determination of the antibody titers. In addition, determination of $\mathrm{CFH}-\mathrm{Ab}$ is also necessary if kidney transplantation is necessary to prevent posttransplant HUS recurrence $(31,32)$.

In conclusion, we present three additional patients with a novel subgroup of aHUS that is characterized by a peculiar combination of genetic (a homozygous deletion of CFHRI/CFHR3) and acquired (development of CFH-Ab) factors. For patients with aHUS, determination of CFH-Ab is necessary not only for correct diagnosis but also for planning a therapeutic strategy.

\section{REFERENCES}

1. Noris M, Remuzzi G 2005 Hemolytic uremic syndrome. J Am Soc Nephrol 16:1035-1050

2. Kavanagh D, Goodship TH, Richards A 2006 Atypical haemolytic uraemic syndrome. Br Med Bull 77-78:5-22

3. Caprioli J, Noris M, Brioschi S, Pianetti G, Castelletti F, Bettinaglio P, Mele C, Bresin E, Cassis L, Gamba S, Porrati F, Bucchioni S, Monteferrante G, Fang CJ, Liszewski MK, Kavanagh D, Atkinson JP, Remuzzi G 2006 Genetics of HUS: the impact of $\mathrm{MCP}, \mathrm{CFH}$, and IF mutations on clinical presentation, response to treatment, and outcome. Blood 108:1267-1279

4. Sellier-Leclerc AL, Frémeaux-Bacchi V, Dragon-Durey MA, Macher MA, Niaudet P, Guest G, Boudailliez B, Bouissou F, Deschenes G, Gie S, Tsimaratos M, Fischbach M, Morin D, Nivet H, Alberti C, Loirat C 2007 Differential impact of complement mutations on clinical characteristics in atypical hemolytic uremic syndrome. J Am Soc Nephrol 18:2392-2400

5. Goicoechea de Jorge E, Harris CL, Esparza-Gordillo J, Carreras L, Arranz EA, Garrido CA, Lopez-Trascasa M, Sanchez-Corral P, Morgan BP, Rodriguez de Cordoba S 2007 Gain-of-function mutations in complement factor B are associated with atypical hemolytic uremic syndrome. Proc Natl Acad Sci USA 104:240-245

6. Frémeaux-Bacchi V, Miller EC, Liszewski MK, Strain L, Blouin J, Brown AL, Moghal N, Kaplan BS, Weiss RA, Lhotta K, Kapur G, Mattoo T, Nivet H, Wong W, Gie S, Hurault de Ligny B, Fischbach M, Gupta R, Hauhart R, Meunier V, Loirat C, Dragon-Durey MA, Fridman WH, Janssen BJ, Goodship TH, Atkinson JP 2008 Mutations in complement C3 predispose to development of atypical hemolytic uremic syndrome. Blood 112:4948-4952

7. Neumann HP, Salzmann M, Bohnert-Iwan B, Mannuelian T, Skerka C, Lenk D, Bender BU, Cybulla M, Riegler P, Konigsrainer A, Neyer U, Bock A, Widmer U, Male DA, Franke G, Zipfel PF 2003 Haemolytic uraemic syndrome and mutations of the factor $\mathrm{H}$ gene: a registry-based study of German speaking countries. J Med Genet 40:676-681

8. Dragon-Durey MA, Frémeaux-Bacchi V 2005 Atypical haemolytic uraemic syndrome and mutations in complement regulator genes. Springer Semin Immunopathol 27:359-374

9. Frémeaux-Bacchi V, Kemp EJ, Goodship JA, Dragon-Durey MA, Strain L, Loirat C, Deng HW, Goodship TH 2005 The development of atypical haemolytic-uraemic syndrome is influenced by susceptibility factors in factor $\mathrm{H}$ and membrane cofactor protein: evidence from two independent cohorts. J Med Genet 42:852-856

10. Esparza-Gordillo J, Goicoechea de Jorge E, Buil A, Carreras Berges L, LopezTrascasa M, Sanchez-Corral P, Rodriguez de Cordoba S 2005 Predisposition to atypical hemolytic uremic syndrome involves the concurrence of different susceptibility alleles in the regulators of complement activation gene cluster in 1q32. Hum Mol Genet 14:703-712

11. Józsi M, Strobel S, Dahse HM, Liu WS, Hoyer PF, Oppermann M, Skerka C, Zipfel PF 2007 Anti factor H autoantibodies block C-terminal recognition function of factor $\mathrm{H}$ in hemolytic uremic syndrome. Blood 110:1516-1518
12. Dragon-Durey MA, Loirat C, Cloarec S, Macher MA, Blouin J, Nivet H, Weiss L, Fridman WH, Fremeaux-Bacchi V 2005 Anti-Factor H autoantibodies associated with atypical hemolytic uremic syndrome. J Am Soc Nephrol 16:555-563

13. Józsi M, Licht C, Strobel S, Zipfel SL, Richter H, Heinen S, Zipfel PF, Skerka C 2008 Factor $\mathrm{H}$ autoantibodies in atypical hemolytic uremic syndrome correlate with CFHR1/CFHR3 deficiency. Blood 111:1512-1514

14. Male DA, Ormsby RJ, Ranganathan S, Giannakis E, Gordon DL 2000 Complement factor $\mathrm{H}$ : sequence analysis of $221 \mathrm{~kb}$ of human genomic DNA containing the entire fH, fHR-1 and fHR-3 genes. Mol Immunol 37:41-52

15. Zipfel PF, Jokiranta TS, Hellwage J, Koistinen V, Meri S 1999 The factor H protein family. Immunopharmacology 42:53-60

16. Dragon-Durey MA, Frémeaux-Bacchi V, Loirat C, Blouin J, Niaudet P, Deschenes G, Coppo P, Herman Fridman W, Weiss L 2004 Heterozygous and homozygous factor $\mathrm{H}$ deficiencies associated with hemolytic uremic syndrome or membranoproliferative glomerulonephritis: report and genetic analysis of 16 cases. J Am Soc Nephrol 15:787-795

17. Schwartz GJ, Haycock GB, Edelmann CM Jr, Spitzer A 1976 A simple estimate of glomerular filtration rate in children derived from body length and plasma creatinine. Pediatrics 58:259-263

18. Kristensen T, Tack BF 1986 Murine protein H is comprised of 20 repeating units, 61 amino acids in length. Proc Natl Acad Sci USA 83:3963-3967

19. Atkinson JP, Liszewski MK, Richards A, Kavanagh D, Moulton EA 2005 Hemolytic uremic syndrome: an example of insufficient complement regulation on self-tissue. Ann N Y Acad Sci 1056:144-152

20. Jokiranta TS, Cheng ZZ, Seeberger H, Jozsi M, Heinen S, Noris M, Remuzzi G, Ormsby R, Gordon DL, Meri S, Hellwage J, Zipfel PF 2005 Binding of complement factor $\mathrm{H}$ to endothelial cells is mediated by the carboxy-terminal glycosaminoglycan binding site. Am J Pathol 167:1173-1181

21. Hellwage J, Jokiranta TS, Friese MA, Wolk TU, Kampen E, Zipfel PF, Meri S 2002 Complement $\mathrm{C} 3 \mathrm{~b} / \mathrm{C} 3 \mathrm{~d}$ and cell surface polyanions are recognized by overlapping binding sites on the most carboxyl-terminal domain of complement factor $\mathrm{H}$. J Immunol 169:6935-6944

22. Kavanagh D, Richards A, Atkinson J 2008 Complement regulatory genes and hemolytic uremic syndromes. Annu Rev Med 59:293-309

23. Józsi M, Heinen S, Hartmann A, Ostrowicz CW, Halbich S, Richter H, Kunert A, Licht C, Saunders RE, Perkins SJ, Zipfel PF, Skerka C 2006 Factor H and atypical hemolytic uremic syndrome: mutations in the C-terminus cause structural changes and defective recognition functions. J Am Soc Nephrol 17:170-177

24. Vaziri-Sani F, Holmberg L, Sjöholm AG, Kristoffersson AC, Manea M, FremeauxBacchi V, Fehrman-Ekholm I, Raafat R, Karpman D 2006 Phenotypic expression of factor $\mathrm{H}$ mutations in patients with atypical hemolytic uremic syndrome. Kidney Int 69:981-988

25. Manuelian T, Hellwage J, Meri S, Caprioli J, Noris M, Heinen S, Jozsi M, Neumann HP, Remuzzi G, Zipfel PF 2003 Mutations in factor $\mathrm{H}$ reduce binding affinity to C3b and heparin and surface attachment to endothelial cells in hemolytic uremic syndrome. J Clin Invest 111:1181-1190

26. Lupski JR, Stankiewicz P 2005 Genomic disorders: molecular mechanisms for rearrangements and conveyed phenotypes. PLoS Genet 1:e49

27. Heinen S, Sanchez-Corral P, Jackson MS, Strain L, Goodship JA, Kemp EJ, Skerka C, Jokiranta TS, Meyers K, Wagner E, Robitaille P, Esparza-Gordillo J, Rodriguez de Cordoba S, Zipfel PF, Goodship TH 2006 De novo gene conversion in the RCA gene cluster (1q32) causes mutations in complement factor $\mathrm{H}$ associated with atypical hemolytic uremic syndrome. Hum Mutat 27:292-293

28. Venables JP, Strain L, Routledge D, Bourn D, Powell HM, Warwicker P, DiazTorres ML, Sampson A, Mead P, Webb M, Pirson Y, Jackson MS, Hughes A, Wood KM, Goodship JA, Goodship TH 2006 Atypical haemolytic uraemic syndrome associated with a hybrid complement gene. PLoS Med 3:e431

29. Zipfel PF, Edey M, Heinen S, Józsi M, Richter H, Misselwitz J, Hoppe B, Routledge D, Strain L, Hughes AE, Goodship JA, Licht C, Goodship TH, Skerka C 2007 Deletion of complement factor H-related genes CFHR1 and CFHR3 is associated with atypical hemolytic uremic syndrome. PLoS Genet 3:e41

30. Coppo P, Bengoufa D, Veyradier A, Wolf M, Bussel A, Millot GA, Malot S, Heshmati F, Mira JP, Boulanger E, Galicier L, Durey-Dragon MA, FremeauxBacchi V, Ramakers M, Pruna A, Bordessoule D, Gouilleux V, Scrobohaci ML, Vernant JP, Moreau D, Azoulay E, Schlemmer B, Guillevin L, Lassoued K 2004 Severe ADAMTS13 deficiency in adult idiopathic thrombotic microangiopathies defines a subset of patients characterized by various autoimmune manifestations, lower platelet count, and mild renal involvement. Medicine (Baltimore) 83:233-244

31. Kwon T, Dragon-Durey M-A, Macher M-A, Baudouin V, Maisin A, Peuchmaur M, Fremeaux-Bacchi V, Loirat C 2008 Successful pre-transplant management of a patient with anti-factor $\mathrm{H}$ autoantibodies-associated haemolytic uraemic syndrome. Nephrol Dial Transplant 23:2088-2090

32. Le Quintrec M, Zuber J, Noel LH, Thervet E, Frémeaux-Bacchi V, Fridman WH, Legendre C, Dragon-Durey MA 2009 Anti-factor H-auto-antibodies in a fifth renal transplant recipient with atypical hemolytic and uremic syndrome. Am J Transplant 9:1223-1229 